

\title{
Digital Database of the Holocene Tephras of the Mono-Inyo Craters, California
}

Data Series 758 


\section{U.S. Department of the Interior \\ KEN SALAZAR, Secretary}

\section{U.S. Geological Survey \\ Suzette M. Kimball, Acting Director}

U.S. Geological Survey, Reston, Virginia: 2013

For more information on the USGS-the Federal source for science about the Earth, its natural and living resources, natural hazards, and the environment-visit http://www.usgs.gov or call 1-888-ASK-USGS

For an overview of USGS information products, including maps, imagery, and publications, visit $h$ ttp://www.usgs.gov/pubprod

Suggested citation:

Bursik, M., and Sieh, K., 2013, Digital database of the Holocene tephras of the Mono-Inyo Craters, California: U.S. Geological Survey Data Series 758.

Any use of trade, firm, or product names is for descriptive purposes only and does not imply endorsement by the U.S. Government.

Although this information product, for the most part, is in the public domain, it also may contain copyrighted materials as noted in the text. Permission to reproduce copyrighted items must be secured from the copyright owner. 


\section{Contents}



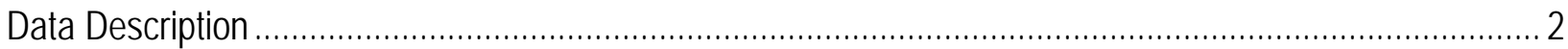

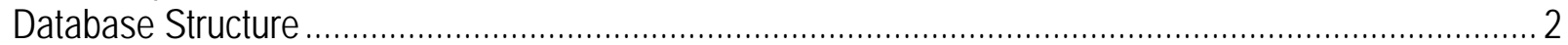

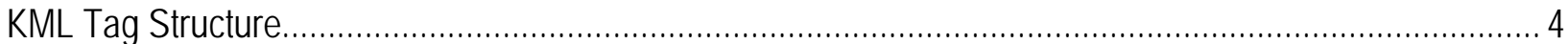



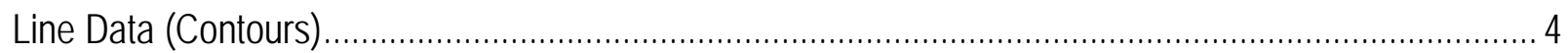

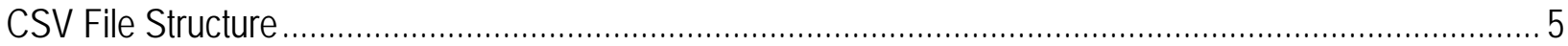

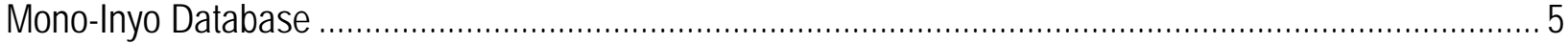

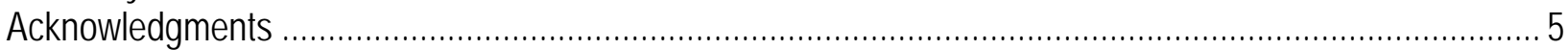

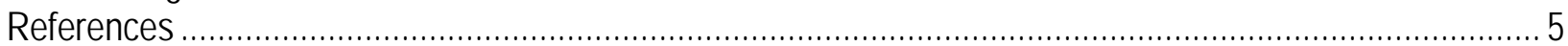

\section{Table}

Table of tephra ages, isopachs, and volumes for_the Mono-Inyo Craters, California. http://pubs.usgs.gov/ds/758/data/monoinyodates.html 
This page intentionally left blank 


\title{
Digital Database of the Holocene Tephras of the Mono-Inyo Craters, California
}

\author{
By Marcus Bursik ${ }^{1}$ and Kerry Sieh ${ }^{2}$
}

\section{Introduction}

This digital product comprises a collection of age and isopach data for the Holocene tephras of the Mono-Inyo Craters, California. Data on the most recent eruptions from this volcanic chain are relatively comprehensive, getting less so the further back in time. For the most recent eruptions to about 1,500 years ago, tephra beds within separate eruptive sequences have been studied and isopached. Before this, from about 2,000 years ago to about 5,000 years ago, there are insufficient data for isopaching. However, one isolated tephra of about 9,000 years ago was studied and isopached in detail.

Regarding ages, there are many tens of radiocarbon ages that have been obtained on the Holocene Mono-Inyo volcanic products (see for example, Bell and House, 2007). The vast majority of these radiocarbon dates are associated with tephras at locales that can be considered distal (basically where the primary tephra is less than several centimeters $(\mathrm{cm})$ thick). These dates represent carbon that was sequestered perhaps within several hundred years of the eruption but do not represent the ages of separate eruptive pulses. There are two reasons for this. In some cases, it is clear that the dated material is not associated with the eruption products. This is the case in some lake strata where carbon is either not physically close to a given tephra layer or where an age for a tephra layer was obtained by interpolation assuming a sedimentation rate. In other cases, it is not clear that a given tephra layer represents a primary tephra; in such cases the layer could instead be redeposited. At most distal localities (beyond about 5 kilometers (km) from the chain), there was no record made of whether tephra was primary or redeposited, and at these distances where tephra is thin, it is generally redeposited during later events such as fires or thunderstorms. These age data are not appropriate for use in dating the eruptive history of the volcanic chain, and are therefore not included in the present contribution.

The carbon age data in the present contribution were obtained by careful consideration of the material being collected. In the best instances, carbon was collected from new growth on plants that were probably killed by an eruption event through burning and burial. Slightly poorer data were collected from burned and buried forest duff that is renewed frequently. Finally, some dates for older Holocene tephra layers at Black Lake, Nevada, downwind of the Mono-Inyo Craters, appear to allow correlation of the layers to proximal occurrences. In cases where these poorer data were collected but yielded ages statistically indistinguishable from better data, the poorer data were included in the analysis. In the most difficult cases, usually the furthest back in time, poorer data that

\footnotetext{
${ }^{1}$ University at Buffalo, State University of New York, Buffalo, New York

${ }^{2}$ Earth Observatory of Singapore, Singapore
} 
were nevertheless statistically indistinguishable were weighted together to generate the age estimate.

There are some known Holocene eruptions from the Mono-Inyo Craters that are not included in this tabulation, as so far a tephra has not been associated with the eruptions. A good example of this is the Java blocks (Stine, 1990). The Java block eruption, from a vent underlying the northwestern corner of Negit Island in Mono Lake, expelled numerous blocks that were rafted within the lake and that are mostly deposited on the southwestern and northern lakeshore. No tephra that can be correlated to this deposit has been found, and therefore the eruption is not included in this tabulation.

\section{Data Description}

\section{Database Structure}

The database is organized in the form of a base table with linked external isopach maps and isopach tabular data. The base table contains data on name and age of tephras, together with any related narrative information. The tephras have been grouped into separate "episodes," which are to some extent subjective divisions. Within each of the separate episodes, an effort has been made to distinguish separate events. With increasing age, it gets more difficult to separate these events one from another given the degradation of radiocarbon accuracy, as well as the paucity of appropriate material for precise radiocarbon analysis that directly ties a date to the tephra under consideration.

The data table contains links to isopach maps and comma separated value (CSV) files for each tephra layer for which isopaching was possible. Both were generated automatically in GRASS GIS software (Grass Development Team, 2012) by querying several tables within a PostGIS geospatially enabled PostgreSQL (http://www.postgis.org, http://www.postgresql.org) relational database containing field data (http://www.volcano.buffalo.edu/monoinyo/), and using GRASS GIS functions to contour the point data and make areal calculations. Volumes were calculated from the isopach data (discussed more below) using automated spreadsheet programs to calculate exponential (Pyle, 1990; Fiestein and Nathenson, 1992) and Weibull function (Bonadonna and Costa, 2012) fits. Note that for clarity and for compatibility with exponential thinning, the maps only contain isopachs for every power of ten decrease in thickness, whereas the CSV files contain isopach data at a very high density. The great advantages to automating the isopaching process is that all data from multiple layers collected by different workers are visualized and treated as consistently as possible, and egregious errors can be located and rectified relatively easily.

The table columns have the following meanings:

Eruption is the name of the eruptive sequence to which a particular tephra belongs. The Eruption would generate all materials erupted within a restricted time from a generally spatially restricted group of vents.

Age, 14C yr BP is the uncorrected carbon-14 age before present of organic materials associate with an Eruption as reported directly from the radiocarbon laboratory. 
1 sigma is one standard deviation in the uncorrected radiocarbon age.

Reference is either the name of the researcher who collected the data for the age determination if unpublished or the published source.

Lab no. is the radiocarbon laboratory code (see http://www.radiocarbon.org/Info/conventional-labs.htm) and laboratory designated analysis number.

Cal. age, cal BP is the calibrated radiocarbon age of the eruption and resulting deposit. Note that in every case, we have tried to supply a true eruption age, rather than a maximum or minimum constraining age. When possible, plants or charcoal from plants that were likely killed by the eruption were used.

Tephra (Vent)/Layer (Vent) is the name of a specific tephra layer or tephra sequence and the vent(s) from which it was erupted. Often the vent is named after a dome that was erupted later and filled the vent. Names of tephra sequences are given in larger font-size than are names of single tephra layers, with known vents given in parentheses. Insofar as possible, a name that is already in use is given, but many of the tephras are herein informally named for the first time. The convention followed in assigning the informal names is that the new name is based on the most proximal locality at which the tephra has been observed.

Deposit volume, $\mathrm{cu} \mathrm{km} / \mathrm{Exp}$, Weibull [Pub'd] is volume of the specific tephra sequence or layer. Without parentheses, this is the volume as calculated in the present work. "Exp" uses the method of Fierstein and Nathenson (1992) for either one or two exponential line segments, depending on which fits data better. "Weibull" uses the method of Bonadonna and Costa (2012) for a Weibull function fit to the data. Both methods use the Thickness "min" (thickness minimum in meters, $\mathrm{m}$ ) and "Cum. area" (cumulative area in square meters, sq $\mathrm{m}$ ) columns in the appropriate CSV table to calculate volume. Thickness "min" is used as this is the thickness value on the outermost margin of the ring designated by the "min" and "max" (thickness maximum values). It is not known if either of the exponential or Weibull fits should in be better than the other. In parentheses is a volume for a tephra sequence as summed from the values of the different tephra layers that comprise the sequence. In square brackets is the volume as reported in previous work. All volumes are deposit volumes, not so-called dense-rock-equivalent volumes.

Map is a link to a downloadable Keyhole Markup Language (KML) file of the tephra that can be opened in Google Earth or any other KML viewer. The maps contain a volcano icon showing the vent position, pushpin icons for sites used in the isopaching, and isopachs. Isopach contour thicknesses are shown in values of $\log _{10}($ thickness, $m$ ), as this is a more natural system of measure for thickness, given the way it decreases with the square-root of increasing isopach area in tephra layers (Pyle, 1990; Fierstein and Nathanson, 1992). Isopaching was done by using a relatively stiff cubic spline on a dataset of all measured thickness values for the given tephra layer. This was implemented in GRASS GIS using the v.surf.rst algorithm, with parameters "tension=50 smooth=20. npmin $=300$ segmax $=200 "$ for proximal parts of deposits and "tension=1. smooth $=1$. npmin=300 segmax=200" for distal parts. Anisotropy factors "theta" and "scalex" were set at default values. Additional, vanishingly small thickness values were added outside 
of the convex hull of each thickness point cloud to ensure that the spline thinned away from the source. Other methods of interpolation were explored (inverse-distance weighted, b-spline, radial basis function and neural network), but none of these so far has yielded results better than the cubic spline in terms of replicating what an expert human would do. Universal Transverse Mercator (UTM) coordinates of the point data displayed in the text boxes associated with each point are in the North American Datum of 1927 (NAD 27) projection referenced to zone 11 North. Both contours and sites can be clicked on for information.

Isopachs is a link to a downloadable CSV file. The CSV tables were created for easy import of the isopach data into Microsoft Excel or other spreadsheet program for those wishing to compute tephra volume using methods other than those used herein. The spreadsheets contain detailed data on isopach encompassed areas. Specifically, the CSV file contains the following data: Thickness max, thickness min, Isopach area, Cum. area.

Remarks consist of any necessary information to understanding the definition, size, or age of the tephra. Generally, most ancillary information in the remarks column concerns the dating of the tephra.

\section{KML Tag Structure}

The KML files contain informational tags that pop up when the area within an isopach or a site pin is clicked in a map browser. The tags for point data (sites) and line data (contours) contain different types of information.

\section{Point Data}

utm_e is the UTM easting coordinate in the NAD27 horizontal datum, zone 11 North. utm $\_n$ is the UTM northing coordinate in the NAD27 horizontal datum, zone 11 North.

Th_m is the thickness of the layer at the site, in meters. For sites where a trace of ash exists or the thickness of primary ash was not given, a nominal thickness of $0.0001 \mathrm{~m}$ is indicated.

sptl_obj_id is the field or reference designation of the site ("spatial object id") name with the following exceptions: data from Wood (1977) are given arbitrary site numbers, with the prefix "Wo77-“; data from Davis (1978) are given site numbers as indicated in the original reference, with the prefix "JOD." The vast majority of the sites are from the authors’ own investigations, with additional data from references as indicated.

sptl_obj_seq is the (arbitrary) designation of the site in the geospatial database.

\section{Line Data (Contours)}

cat is the (arbitrary) designation of the category of the contour level in the geospatial database.

Th_log_10_m is the thickness of the isopach contour in meters, taken to the base-10 logarithm. Thus, for example, “-3” is $1 \mathrm{~mm}$. 


\section{CSV File Structure}

Thickness [m], min and max are the thickness values in meters of the isopachs that define the edges of a ring having area of "Isopach area" (next column).

Isopach area [sq $\mathrm{m}]$ is the area in square meters within the ring defined by the max and min isopachs. Note that the smallest area is one pixel at a nominal map resolution of $1 \mathrm{~km}$. This area is just under $10^{6} \mathrm{~m}^{2}=1 \mathrm{~km}^{2}$.

Cum. area $[\mathrm{sq} \mathrm{m}]$ is the sum of the areas in square meters within the rings beginning with the ring of greatest thickness (encircling the vent). Note that the calculations of cumulative area were done in single-precision floating point. Therefore, there will be some difference between the numbers shown and those obtained if recalculated in a spreadsheet program that uses double-precision floating-point format.

\section{Mono-Inyo Database}

Table of tephra ages, isopachs, and volumes for_the Mono-Inyo Craters, California. http://pubs.usgs.gov/ds/758/data/monoinyodates.html

\section{Acknowledgments}

Data were collected in part under grants from the U.S. Geological Survey (USGS); National Aeronautics and Space Administration (NASA); University at Buffalo, State University of New York; and the National Science Foundation (NSF). The database was constructed with funds from NASA, University at Buffalo, USGS, and NSF.

\section{References}

$\left[{ }^{1}\right.$ Sources for published data on an eruption that resulted in tephra layers. ${ }^{2}$ Sources for published data on ash occurrence.]

${ }^{2}$ Batchelder, G., 1970, Postglacial Ecology at Black Lake, Mono County, California: Arizona State University, unpublished Ph.D. dissertation, 180 p.

${ }^{2}$ Bell, J.W., dePolo, C.M., Ramelli, A.R., Sarna-Wojcicki, A.M., and Meyer, C.E., 1999, Surface faulting and paleoseismic history of the 1932 Cedar Mountain earthquake area, west-central Nevada, and implications for modern tectonics of the Walker Lane: Geological Society of America Bulletin, v. 111, p. 791-807.

${ }^{2}$ Bell, J.W., and House, P.K., 2007, Did Plinian eruptions in California lead to debris flows in Nevada?-An intriguing stratigraphic connection: Geology, v. 35, p. 219-222.

Benson, L., Linsley, B., Smoot, J., Mensing, S., Lund, S., Stine, S., and Sarna-Wojcicki, A., 2003, Influence of the Pacific Decadal Oscillation on the climate of the Sierra Nevada, California and Nevada: Quaternary Research, v. 59, p. 151-159.

Bonadonna, C., and Costa, A., 2012, Estimating the volume of tephra deposits-A new simple strategy: Geology, v. 40, no. 5, p. 415, doi:10.1130/G32769.1. 
${ }^{1}$ Browne, B., M. Bursik, Deming, J., Louros, M., Martos, A., and Stine, S., 2010, Eruption chronology and petrologic reconstruction of the ca. 8,500 BP eruption of Red Cones, southern Inyo chain, California: Geological Society of America Bulletin, v. 122 p. 1401-1422.

Bursik, M., Renshaw, C., McCalpin, J., and Berry, M., 2003, A volcanotectonic cascade-Activation of range front faulting and eruptions by dike intrusion, Mono Basin-Long Valley Caldera, California: Journal of Geophysical Research, v. 108, no. B8, p. 2393, doi:10.1029/2002JB002032.

${ }^{2}$ Davis, J.O., 1978, Quaternary tephrochronology of the Lake Lahontan area, Nevada and California: Nevada Archeological Survey Research Paper 7, 137 p.

Fierstein, J., and Nathenson, M., 1992, Another look at the calculation of fallout tephra volumes: Bulletin of Volcanology, v. 54, p. 156.

GRASS Development Team, 2012, Geographic Resources Analysis Support System (GRASS) Software, Version 6.4.1: Open Source Geospatial Foundation Web site, accessed March 11, 2013, at http://grass.osgeo.org.

Millar, C.I., King, J.C., Westfall, R.D., Alden, H.A., and Delany, D.L., 2006, Late Holocene forest dynamics, volcanism, and climate change at Whitewing Mountain and San Joaquin Ridge, Mono County, Sierra Nevada, CA, USA: Quaternary Research, v. 66, p. 273-287.

${ }^{1}$ Miller, C.D., 1985, Holocene eruptions at the Inyo volcanic chain, California; implications for possible eruptions in Long Valley Caldera: Geology, v. 13, p. 14-17.

Pyle, D.M., 1990, The thickness, volume and grainsize of tephra fall deposits: Bulletin of Volcanology, v. 51, p. 1-15.

${ }^{2}$ Sarna-Wojcicki, A.M., LaJoie, K.R., Meyer, C.E., Adam, D.P., Robinson, S.W., and Anderson, R.S., 1988, Tephrochonologic studies of sediment cores from Walker Lake, Nevada: U.S. Geological Survey Open-File Report 88-548, 25 p.

${ }^{1}$ Sieh, K., and M. Bursik, M., 1986, Most recent eruption of the Mono Craters, eastern Central California: Journal of Geophysical Research, v. 91, p. 12539-12571.

Sorey, M.L., Evans, W.C., Kennedy, B.M., Farrar, C.D., Hainsworth, L.J., and Hausback, B., 1998, Carbon dioxide and helium emissions from a reservoir of magmatic gas beneath Mammoth Mountain, California: Journal of Geophysical Research, v. 103, p. 15303-15323.

Stine, S., 1990, Late Holocene fluctuations of Mono Lake, eastern California: Palaeogeography, Palaeoclimatology, Palaeoecology, v. 78, p. 333-381.

${ }^{2}$ Wood, S.H., 1977, Distribution, correlation, and radiocarbon dating of late Holocene tephra, Mono and Inyo craters, eastern California: Geological Society of America Bulletin, v. 88, p. 89-95.

${ }^{2}$ Wood, S., 1983, Chronology of late Pleistocene and Holocene volcanics, Long Valley and Mono Basin geothermal areas, eastern California. U.S. Geological Survey Open-File Report 83-747, 76 p. 